\title{
KAJIAN PENGOBATAN PASIEN KANKER SERVIKS DI RSUD ABDUL WAHAB SJAHRANIE SAMARINDA
}

\author{
Sibarani Evy Morita*, Wisnu Cahyo Prabowo, Laode Rijai \\ Laboratorium Penelitian dan Pengembangan FARMAKA TROPIS, Fakultas \\ Farmasi,Universitas Mulawarman, Samarinda, Kalimantan Timur \\ *email: sibaranievy@gmail.com
}

\begin{abstract}
ABSTRAK
Kanker serviks merupakan penyebab utama kematian akibat kanker di usia reproduktif pada wanita di negara-negara berkembang. Kanker serviks adalah kanker yang menyerang leher rahim dan ditandai dengan pertumbuhan abnormal sel pada leher rahim. Penelitian ini bertujuan untuk mengetahui karakteristik dan jenis pengobatan pasien kanker serviks di instalasi rawat inap di RSUD Abdul Wahab Sjahranie Samarinda. Metode penelitian yang digunakan berupa penelitian non eksperimental yang dilakukan secara retrospektif. Dianalisis dengan metode analisis deskriptif dan kuantitatif. Hasil penelitian yang diperoleh pada penelitian ini yaitu diketahui pasien kanker serviks paling banyak terjadi pada pasien usia 45 hingga 49 tahun dengan stadium terbanyak yaitu stadium IIIA $(37,5 \%)$. \%). Tingkat pendidikan terakhir yaitu Sekolah Dasar $(45,83 \%)$ dan jenis pekerjaan pasien sebagai ibu rumah tangga $(89,58 \%)$ dengan tingkat paritas lebih dari $4(54,17 \%)$. Jenis pengobatan yang paling banyak dilakukan yaitu kemoterapi $(81,24 \%)$ kemudian pembedahan $(2,08 \%)$ serta tindakan biopsi $(16,67 \%)$. Pemilihan obat untuk terapi kanker serviks dengan kombinasi obat tertinggi yaitu kombinasi paxus-carboplatin $(77,08 \%)$ dan kombinasi cisplatin-vinkristinbleomycin $(4,16 \%)$.
\end{abstract}

Kata kunci : kanker serviks, karakteristik, pola pengobatan.

\section{ABSTRACT}

Cervical cancer is the leading cause of cancer deaths in women of reproductive age in developing countries. Cervical cancer is cancer that attacks the cervix and is characterized by the abnormal growth of cells in the cervix. This study aims to determine the characteristics and patterns of treatment of cervical cancer patients at hospitalization installation in General Hospital Abdul Wahab Sjahranie Samarinda. The method used is non-experimental research conducted retrospectively. The analyzed using descriptive analysis. The results obtained in this study is unknown cervical cancer patients is most prevalent in patients aged 45 to 49 years with most stadiums are stage III A (37.5\%). The education level is elementary school (45.83\%) and the patient's occupation as housewife (89.58\%) with parity rate of more than 4 (54.17\%). Therapeutic treatment of the most widely performed is chemotherapy (81.24\%, surgery (2.08\%) and biopsy (16.67\%). Selection of drugs for the treatment of cervical cancer in combination with the highest drug-carboplatin combination paxus (77.08\%) and the combination of cisplatin-vincristine-bleomycin (4.16\%).

Keywords: cervical cancer, characteristics, treatment patterns. 


\section{PENDAHULUAN}

Kanker serviks atau karsinoma serviks uteri nerupakan salah satu penyebab utama kematian wanita yang berhubungan dengan kanker. Dalam waktu 10 tahun terakhir, dilaporkan bahwa kanker merupakan penyebab kematian dari peringkat ke 12 menjadi ke 6 di Indonesia. Hal ini terjadi karena keterlambatan pasien kanker serviks untuk memeriksakan diri ke pelayanan kesehatan, sehingga pada saat didiagnosis awal menderita kanker serviks, ternyata sudah dalam stadium lanjut yang menyebabkan angka kematian semakin meningkat. Berdasarkan laporan patologi anatomi di Indonesia tersebut di antara 10 jenis kanker, kanker serviks menduduki peringkat teratas sebagai penyebab kematian bagi perempuan Indonesia (Dewi et. Al.2012).

Menurut Arisusilo et al.(2012), di Indonesia kanker serviks menduduki tempat kedua dalam urutan keganasan pada wanita yaitu 16 orang per 100.000 penduduk wanita. Berdasarkan pada Sistem Informasi Rumah Sakit (SIRS) 2007, kejadian kanker serviks sebanyak 5.786 kasus atau 11,78 \% dari keganasan lainnya. Angka kejadian kanker serviks meningkat dari jumlah kasus pada 2006 sebanyak 4.696 kasus atau 11,07 \% dan sekitar 70 $\%$ penderita berada dalam stadium lanjut. Sedangkan berdasarkan pada Pusat Data dan Informasi Kementrian Kesehatan (Depkes RI)2015, secara nasional prevalensi penyakit kanker pada penduduk seumur umur di Indonesia sebesar 1,4\% atau diperkirakan sekitar 347.792 orang dan untuk daerah Kalimantan Timur sendiri ada sebesar 752 orang.

Kanker serviks merupakan penyakit ginekologik yang memiliki tingkat keganasan yang cukup tinggi dan menjadi penyebab kematian utama akibat kanker pada wanita di negara-negara berkembang. Kanker serviks merupakan keganasan yang terjadi pada leher rahim dan disebabkan oleh infeksi Human Papilloma Virus (HPV). Pada penyakit kanker serviks menunjukkan adanya sel-sel abnormal yang terbentuk oleh sel-sel jaringan yang terjadi pada penderita kanker serviks yang tumbuh terus menerus dan tidak terbatas pada bagian leher rahim (Fitriana et al. 2012).

\section{METODE PENELITIAN}

Penelitian ini merupakan penelitian non eksperimental dan merupakan studi retrospektif dengan menggunakan desain deskriptif dan kuantitatif. Teknik Pengambilan data dari penelitian ini diperoleh data sekunder yang berasal dari rekam medik pasien kanker serviks di RSUD Abdul Wahab Sjahranie Samarinda periode 2014-2015. Hasil yang diperoleh di catat, lalu dianalisis hingga memperoleh suatu kesimpulan. Penelitian ini akan dilaksanakan dalam 3 bulan dari bulan juli hingga agustus 2016 dan dilakukan di ruang Rekam Medik, RSUD Abdul Wahab Sjahranie Samarinda. Variabel yang diamti adalah usia, paritas, pekerjaan,tingkat pendidikan,stadium, jenis pengobatan, serta kombinasi obat kemoterapi yang digunakan.

\section{HASIL DAN PEMBAHASAN}

\section{Karakteristik Pasien}

Usia merupakan salah satu faktor resiko dari penyebab terinfeksinya kanker serviks. Berdasarkan beberapa penelitian menunjukkan bahwa wanita yang dapat terkena kanker serviks berada pada usia yang produktif. Karena untuk penyakit kanker serviks memerlukan waktu untuk dapat berkembang dari proses displasia yang biasanya merupakan tumor jinak (benigna) menjadi kanker invasif. Berdasarkan hasil penelitian, dari 48 kasus kanker serviks yang ditemukan di RSUD Abdul Wahab Sjahranie Samarinda bahwa distribusi usia yang paling banyak mengalami kanker serviks yaitu pada usia 45-49 tahun. Hal ini sesuai dengan penelitian Lasut et al.(2015) yang menyatakan bahwa kanker serviks timbul pada usia produktif yaitu usia tiga puluh tahunan atau lebih. 
Selain usia paritas juga merupakan salah satu faktor resiko dari terjadinya kanker serviks. Paritas merupakan jumlah kelahiran. Paritas dapat menyebabkan kanker serviks disebabkan karena semakin sering seseorang wanita menjalani persalinan maka dapat menyebabkan jalan lahir menjadi longgar dan robekan selaput serviks yang terjadi saat persalinan akan menyebabkan terbukanya jaringan sehingga dapat beresiko tinggi untuk terkontaminasi oleh virus HPV. Diketahui bahwa jumlah paritas yang terjadi dari 48 kasus ternyata didominasi oleh wanita dengan jumlah melahirkan $\geq \mathrm{P}_{4}$ atau dengan pasien yang memiliki jmlah persalinan ebih dari 4 kali.

Pekerjaan juga merupakan salah satu dari faktor pendukung dari terjadinya kanker serviks. Berdasarkan hasil yang ditemukan, bahwa penderita kanker serviks dari 48 kasus pekerjaanya didominasi dengan wanita yang memiliki pekerjaan sebagai IRT (Ibu Rumah Tangga) sebanyak 43 kasus atau sebesar 89,58 \%. Hasil ini tidak dapat menjelaskan bahwa bagaimana pekerjaan sebagai IRT dapat menjadi sebagai faktor resiko untuk dapat terinfeksi kanker serviks. Akan tetap pekerjaan sebagai IRT harus diteliti lebih lanjut, karena kemungkinaan besar pasien yang mengaku sebagai IRT tidak menjelaskan secara terperinci lagi pekerjaanya yang sebenarnya (Arususilo, 2012).

Karakteristik pasien yang selanjutnya adalah tingkat pendidikan. Tingkat pendidikan seseorang dapat mendukung atau mempengaruhi seseorang tingkat pengetahuan seseorang. Pendidikan yang rendah menyebabkan seseorang tidak peduli terhadap program kesehatan yang ada, sehingga banyak wanita yang dapat terinfeksi penyakit kanker serviks. Hal ini didukung dengan hasil penelitian yang menunjukkan bahwa dalam 48 kasus kanker serviks yang ditemukan sebagian besar memiliki tingkat pendidikan yang rendah. Tingkat pendidikan yang terbanyak yaitu Sekolah Dasar (SD) sebanyak 22 kasus $(45,83 \%)$. Hasil ini menunjukkan bahwa semakin rendah pendidikan maka dapat berpengaruh dengan kurangya pengetahuan seseorang mengenai deteksi dini kanker serviks maupun mengenai pencegahanya (Dewi et al, 2012).

Stadium merupakan tingkat penyakit yang biasa digunakan untuk menunjukkan keparahan pada pasien kanker. Berdasarkan hasil penelitian menunjukkan bahwa dalam 48 kasus kanker serviks yang ditemukan sebagian besar terjadi dengan pasien stadium klinis IIIA yaitu sebanyak 18 kasus (37,5\%). Hasil ini menujukkan bahwa pasien terlambat mengetahui bahwa dirinya terinfeksi penyakit kanker serviks. Hal ini disebabkan karena kurangnya pengetahuan mengenai deteksi dini kanker serviks sehingga kebanyakan pasien datang dalam status stadium yang telah tinggi, hal ini didukung dengan hasil penelitian yang dikemukakan oleh Dewi et al.(2012) sebagian besar pasien memiliki rasa takut ataupun malu untuk memeriksakan dirinya ke rumah sakit sehingga pasien kanker serviks datang dengan kondisi telah berada pada stadium yang tinggi.

\section{Jenis pengobatan dan Kombinasi obat Kemoterapi}

\section{Jenis pengobatan}

Dalam pengobatan kanker serviks ada beberapa jenis pengobatan yang dilakukan yaitu pembedahan, radioterapi, dan kemoterapi. Pada hasil yang sebelumnya menunjukkan bahwa dalam 48 kasus kanker serviks yang ditemukan sebagian besar berada pada stadium lanjut yaitu pada stadium IIIA dengan jenis pengobatan yang didominasi oleh kemoterapi. Menurut Naland (2007) kemoterapi adalah cara pengobatan dengan memberikan obat pembasmi sel kanker (sitostatika) yang diminum ataupun yang diinfuskan ke pembuluh darah. Menurut guideline European Society Medical Oncology (2012) untuk pengobatan kanker serviks pada stadium IIB, III, dan IV sendiri dapat menggunakan kemoterapi dengan kombinasi radiaoterapi seperti brachytherapy. Akan tetapi untuk kasus pasien kanker serviks di RSUD Abdul Wahab Sjahranie Samarinda didominasi oleh jenis pengobatan dengan mengunakan kemoterapi 
sebanyak 39 kasus $(81,25 \%)$. Hal ini dapat disebabkan oleh mininya peralatan untuk melakukan brachytherapy dan juga akan semakin menyulitkan pengobatan pasien karena jika menggunakan kombinasi tersebut akan dapat membuat pengobatan semakin mahal.

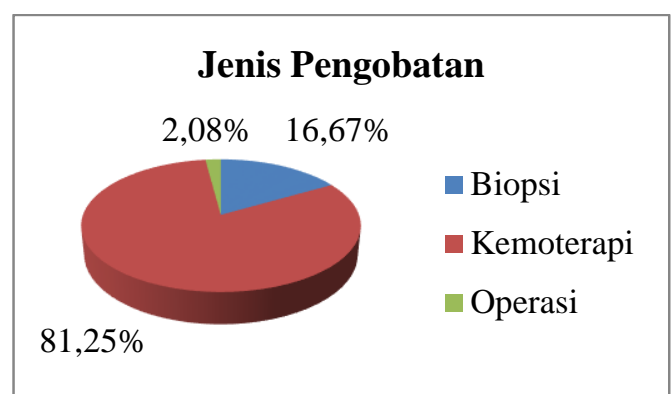

Gambar 1. Klasifikasi Jenis pengobatan pada pasien Kanker serviks

\section{Kombinasi obat kemoterapi}

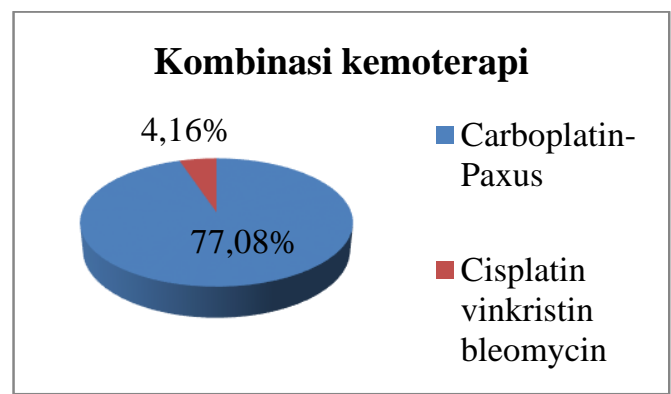

Gambar 2. Klasifikasi Kombinasi obat kemoterapi pada pasien Kanker serviks

Kemoterapi biasanya dilakukan dengan menggunakan kombinasi obat. Kemoterapi kombinasi bertujuan untuk memperbaiki lajunya respons dan memperbaiki daya ketahanan hidup. kombinasi obat pada kemoterapi yang paling banyak digunakan dapat dilihat dari gambar 2, terlihat bahwa kombinasi obat untuk jenis pengobatan kemoterapi banyak digunakan yaitu carboplatin-paxus yaitu sebanyak 37 kasus $(77,08 \%)$. Menurut guideline NCCN (2016), pada kanker serviks obat kemoterapi yang merupakan lini pertama yaitu menggunakan obat dengan golongan derivat platinum. Obat pada golongan ini merupakan cisplatin. Berdasarkan hasil yang ditemukan penggunaan obat tidak sesuai hal ini dikarenakan kebanyakan dari pasien menggunakan carboplatin. Hal ini dapat disebabkan karena penggunaan carboplatin lebih baik jika dilihat dari efek samping dibandingkan cisplatin. Untuk kombinasi obat kemoterapi itu sendiri, carboplatin dikombinasikan dengan paxus karena kedua obat ini dapat bekerja denga sinergis dan maksimal dengan efek samping yang lebih rendah dibandingkan dengan kombinasi obat cisplatin-vinkristin-bleomycin. Seperti yang kita ketahui dalam pengobatan dengan menggunakan kemoterapi banyak efek samping yang akan dialami, sehingga pasien akan lebih memilih regimen obat yang memberikan efek samping yamg lebih rendah. Sedangkan untuk pemilihan regimen PVB sendiri didasarkan oleh harganya yang lebih murah dibandingkan carboplatin paxus.(Santoso, 2011). 


\section{KESIMPULAN}

Berdasarkan hasil penelitian dapat terlihat bahwa kanker serviks paling banyak terjadi pada wanita dengan usia produktif yaitu pada usia 45 hingga 49 tahun dengan keadaan saat dating kerumah sakit pada tingkat stadium yang sudah tinggi. Hal ini dapat disebabkan oleh beberapa faktor resiko yaitu tingkat pendidikan yang rendah dan juga jenis pekerjaan serta tingkat paritas yang tinggi. Jenis pengobatan yang paling banyak dilakukan yaitu kemoterapi dengan kombinasi obat tertinggi yaitu kombinasi paxus-carboplatin.

\section{DAFTAR PUSTAKA}

Arisusilo, C. 2012. Kanker leher rahim (kanker serviks) sebagai pembunuh wanita terbanyak di Negara berkembang. Jurnal sainstis. Vol.1 No.1. Hal 4.

Santoso, Cucuk., dan Brahmana Askandar. 2011. Keberhasilan Kemoterapi Neoajuvan Cisplatin-Vincristine-Bleomycin dan Paclitaxel-Caboplatin Ditinjau dari Penilaian Operabilitas Kanker Serviks IIB. Majalah Obstetri \& Ginekologi. Vol.19 No.3 Hal 221.

Depkes RI. 2015. Pusat Data dan Informasi, Stop Kanker. Departemen Republik Indonesia: Jakarta.

Dewi, Ratna. S., Sari, L, dan Rabiah. 2012. Faktor yang Mempengaruhi Keterlambatan Klien Kanker Serviks Memeriksakan Diri ke Pelayanan Kesehatan. Jurnal Penelitian Kesehatan. Vol. 10 No. 1. Hal 3.

Lasut, Edwin., Max Rarung, dan Erna Suparman. 2015. Karakteristik Penderita Kanker Serviks Di BLU RSUP Prof.Dr.R.D.Kandou. Jurnal e-Clinic (eCl). Vol. 3 No 1. Hal 83-85.

Fitriana, Nimas., dan Ambarini, T. 2012. Kualitas Hidup Pada Penderita Kanker Serviks Yang Menjalani Pengobatan Radioterapi Jurnal Psikologi Klinis dan Kesehatan Mental. Vol. 1 No. 2. Hal 124. 